\title{
'Scissor deformity' of the toes
}

\author{
Ashu Rastogi, Anil Bhansali
}

Department of Endocrinology, Post Graduate Institute of Medical Education and Research, Chandigarh, India

\section{Correspondence to} Dr Anil Bhansali, anilbhansaliendocrine@gmail. com

$A R$ and $A B$ contributed equally.

Accepted 24 April 2017

\section{DESCRIPTION}

A 63-year-old woman presented with an unusual foot deformity involving the left first and second toe causing persistent pain (subjective functional grade 1$),{ }^{1}$ difficulty in walking and inability to accommodate the foot in regular footwear. She has type 2 diabetes mellitus for the past 8 years and sensorimotor peripheral neuropathy as assessed by vibration perception threshold $>25 \mathrm{mV}$, absence of Semmes-Weinstein monofilament perception and absent ankle reflex. She was a home maker and wore footwear with thumb-hold most of the time. On examination, she had severe hallux valgus $(\mathrm{HV})$ (Manchester Scale: severe score $=3)^{2}$, anatomical grade $1^{1}$ and over-riding of second toe over the great toe causing 'scissor deformity' (figure 1). In addition, she had hammer and claw toe deformity involving other digits. She was provided with modified footwear to accommodate great toes with a bunion aid.

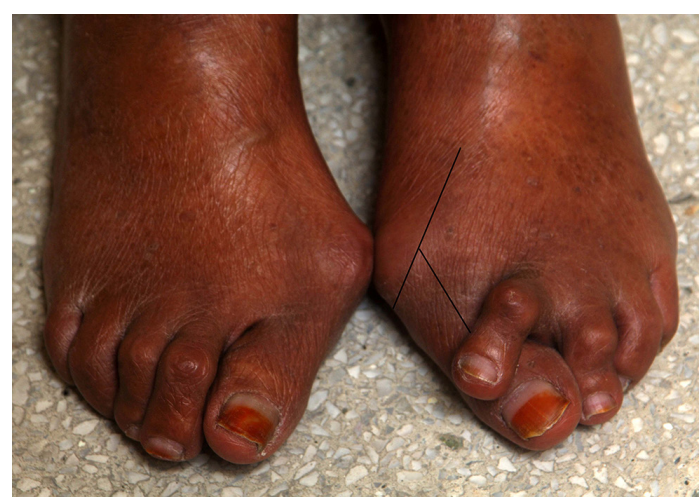

Figure 1 Both feet showing hallux valgus (left more than right), bunion at the first metatarsophalangeal joint, hammer toe deformities of bilateral second and third toe and claw toe deformity of fourth and fifth toe. The angle between the long axis of left first metatarsal and proximal phalanx is $53^{\circ}$, suggestive of severe hallux valgus deformity.
HV is characterised by the lateral deviation of the first toe with medial deviation of the first metatarsal and prominence of the first metatarsophalangeal (MTP) joint. Patients with diabetes are predisposed for HV due to underlying motor neuropathy causing biomechanical instability of MTP joint. The 'scissor deformity' occurred as a result of severe HV causing over-riding of second toe over the great toe. Severe HV is associated with difficulty in wearing footwear, gait instability, foot pain, neuropathic foot ulcers and toe amputation. Hence, careful foot examination, an early recognition of motor neuropathy and counselling for appropriate footwear are the key to prevent HV.

\section{Learning points}

- Early recognition of motor neuropathy may prevent hallux valgus.

- Counselling for appropriate footwear in patients with diabetes is useful to prevent deformities of foot including hallux valgus.

- Severe hallux valgus may require surgical correction.

Contributors AR identified the patient, wrote the manuscript and involved in patient care. $A B$ edited the manuscript and involved in patient care.

Competing interests None declared.

Patient consent Obtained.

Provenance and peer review Not commissioned; externally peer reviewed.

(c) BMJ Publishing Group Ltd (unless otherwise stated in the text of the article) 2017. All rights reserved. No commercial use is permitted unless otherwise expressly granted.

\section{REFERENCES}

1 Smith RW, Reynolds JC, Stewart MJ. Hallux valgus assessment: report of Research Committee of American Orthopaedic Foot and Ankle Society. Foot Ankle 1984:5:92-103.

2 Garrow AP, Papageorgiou A, Silman AJ, et al. The grading of hallux valgus. the Manchester scale. J Am Podiatr Med Assoc 2001;91:74-8.
Copyright 2017 BMJ Publishing Group. All rights reserved. For permission to reuse any of this content visit

http://group.bmj.com/group/rights-licensing/permissions.

BMJ Case Report Fellows may re-use this article for personal use and teaching without any further permission.

Become a Fellow of BMJ Case Reports today and you can:

- Submit as many cases as you like

- Enjoy fast sympathetic peer review and rapid publication of accepted articles

- Access all the published articles

- Re-use any of the published material for personal use and teaching without further permission

For information on Institutional Fellowships contact consortiasales@bmjgroup.com

Visit casereports.bmj.com for more articles like this and to become a Fellow 